\title{
Bioactive compounds in the stem bark of Albizia coriaria (Welw. ex Oliver)
}

\author{
Robert BYAMUKAMA ${ }^{1 *}$, Ganza BARBARA ${ }^{2}$, Jane NAMUKOBE ${ }^{1}$, \\ Matthias HEYDENREICH ${ }^{3}$ and Bernard T. KIREMIRE ${ }^{1}$ \\ ${ }^{I}$ Department of Chemistry, College of Natural Sciences, Makerere University, P.O. Box 7062, Kampala, \\ Uganda. \\ ${ }^{2}$ Chemistry Department, Faculty of Science, Kyambogo University, P.O. Box 1, Kyambogo, Uganda. \\ ${ }^{3}$ Institut für Chemie, Universität Potsdam, P.O. Box 60 15 53, D-14415 Potsdam, Germany. \\ *Corresponding author, E-mail: rbyamukama@cns.mak.ac.ug, Tel.: +256-701-548558
}

\begin{abstract}
Albizia coriaria was investigated for the bioactive compounds present in its stem bark. The plant was selected on the basis of its widespread use in traditional herbal medicine. Extraction of the plant material was done with ethyl acetate, methanol and water and the bioactivity of each extract was tested against Pseudomonas aeruginosa and Escherichia coli. Separation and purification of the compounds in the most active (ethyl acetate) extract was done using a combination of chromatographic techniques. The compounds were identified by $1 \mathrm{D}$ and $2 \mathrm{D}-{ }^{1} \mathrm{H}$ and ${ }^{13} \mathrm{C}$ NMR techniques as well as Mass spectrometry (MS). Six compounds, namely: Lupeol (1), Lupenone (2), Betulinic acid (3), Acacic acid lactone (4), (+) - Catechin (5) and Benzyl alcohol (6) were identified and characterized from the ethyl acetate extract. The results of the bioactivity tests carried out in this study indicated that $A$. coriaria has potential antimicrobial activity. Four of the characterized compounds $(\mathbf{1}, \mathbf{2}, \mathbf{3} \& \mathbf{5})$ have a wide range of biological activity reported in literature. This justifies the use of this plant in traditional medicine and indicates a promising potential for the development of medicinal agents from $A$. coriaria stem bark.

(C) 2015 International Formulae Group. All rights reserved.
\end{abstract}

Keywords: Biological activity, Lupeol, Lupenone, Betulinic acid, Acacic acid lactone, (+) - Catechin.

\section{INTRODUCTION}

Albizia coriaria (Welw. ex Oliver) belongs to the genus Albizia, which consists of about 150 species of mostly fast-growing subtropical and tropical trees and shrubs in the subfamily Mimosoideae of the legume family Fabaceae, with the greatest diversity in Africa and South America (Abdel-Kader et al., 2001). In Uganda, A. coriaria is known locally as Musita (Lusoga), Mugavu (Luganda) and Musiisa (Rukiga) (Namukobe et al., 2011). The bark of $A$. coriaria is harvested locally for the treatment of cough, sore throats, syphilis, skin diseases, jaundice, eye diseases and for use as a general tonic (Namukobe et al., 2011). Its bark has also been reported to have anti-plasmodial activity (Kigondu et al., 2009). In ethnoveterinary, the bark has been reported to be useful in the treatment of anaplamosis, liver flukes and diarrhea (Tabuti and Mugula, 2007). Triterpene glycosidese have been reported in several species from the genus Albizia (Carpani et al., 1989; Orsini et al., 1991). 
Three acacic acid lactone glycosides were reported from the bark of $A$. lebbeck, $A$. julibrissin, A.grandibracteata and A. procera (Zheng et al., 2006; Pal et al., 1995; Yoshikawa et al., 1998; Krief et al., 2005). This paper reports bioactive compounds isolated from the ethyl acetate extract of the stem bark of $A$. coriaria that could be responsible for some of its reported medicinal properties.

\section{MATERIALS AND METHODS Plant collection}

The fresh stem bark of Albizia coriaria was collected in June 2012, from Mukono district, Uganda after identification and authentication by a taxonomist from the department of Botany, Makerere University. Voucher spacimen voucher No. GB 01 has been deposited at Makerere University Herbarium. The stem bark sample was packed in polythene bags and transported to Makerere University.

\section{Preparation of the extracts}

The bark was chopped into small pieces and air dried at room temperature for 21 days. The dry bark was ground into fine powder using an electric grinder. The powdered plant material (1 kg) was sequentially extracted three times with $5 \mathrm{~L}$ of ethyl acetate, methanol and water at room temperature for 48 hours. The extracts were filtered through cotton wool and Whatman No. 1 filter paper and concentrated with a rotary evaporator at $40{ }^{0} \mathrm{C}$ to dryness. The dried extracts were transferred to sample bottles which were placed in a dessicator containing anhydrous sodium sulphate to remove any traces of water that could have been present. The dry extracts were later kept in tightly stoppered bottles in a refrigerator for further analysis.

\section{Testing for selected antimicrobial activity}

The activity of the plant extracts was tested against two American Type Culture Collection (ATCC) bacterial strains: Pseudomonas aeruginosa and Escherichia coli (ATCC 25922) both of which were obtained from the Department of Pharmacology (Makerere University Medical School, Kampala). The bacterial strains were selected on the basis of the diseases against which A. coriaria is used. The bark of $A$. coriaria is used locally for the treatment of cough (commonly caused by $P$. aeruginosa) and diarrhea (caused by E. coli). Testing of the plant extracts for antibacterial activity was done by the modified agar disc diffusion method (Baris et al., 2006). The most active extract was selected for fractionation and further analysis.

\section{Modified agar disc diffusion assay for bacterial screening}

The test microorganism was aseptically inoculated (approx. $1.0 \times 10^{8}$ colony forming units $/ \mathrm{ml}$ ) on sterile Mueller Hinton agar by surface spreading to make a uniform microbial inoculum. Using sterile glass cork borers (6 $\mathrm{mm}$ in diameter), two wells were carefully made on the agar plate without distorting the media; both wells contained the test extract. A separate agar plate was used to test the control drug; ciprofloxacin (0.5 $\mathrm{mg} / \mathrm{ml}$ ) against the bacteria. The second plate containing dimethyl sulfoxide (DMSO) was used as a negative control. Fifty microliters $(50 \mu \mathrm{l})$ of the extract and the controls were carefully dispensed into the respective wells and the plates left on the bench for 60 minutes to allow the system stabilize as the inoculated microorganisms get acclimatized to the new environment. The culture plates were then incubated at $37{ }^{0} \mathrm{C}$ for 24 hours. Using a metric ruler, the diameter of the zone of inhibition (the diameter of the area of no growth of the microorganism around the disc) was measured for the ethyl acetate, methanol and aqueous extracts (Baris et al., 2006).

\section{Determination of Minimum Inhibitory Concentration (MIC) using Broth dilution method}

MIC was performed on organisms that exhibited highest sensitivity, to the ethyl 
acetate extract, of diameter above $12 \mathrm{~mm}$ upon screening. Five hundred microliters of the test extract was serially diluted from 2fold to 4-fold dilution in sterile Mueller Hinton broth. Five hundred microlitres (500 $\mu \mathrm{l})$ of the test organism was aseptically inoculated in each of the four tubes containing the extract in order of increasing dilution (500, 250, 125 and $62.5 \mathrm{mg} / \mathrm{ml})$. Thereafter, the tubes were incubated at $37{ }^{\circ} \mathrm{C}$ for 24 hours (Baris et al., 2006). After incubation, the tube next to the one showing no microorganism turbidity was considered as containing the MIC of the extract in question.

\section{Determination of Minimum Bactericidal Concentration (MBC)}

Following the MIC determination using the Broth dilution method, after the recommended period of incubation, four millilitres $(4 \mathrm{ml})$ of solution from each of the four tubes containing the ethyl acetate extract in order of increasing dilution (500, 250, 125 and $62.5 \mathrm{mg} / \mathrm{ml}$ ) was inoculated on Mueller Hinton agar and incubated at $37{ }^{\circ} \mathrm{C}$ for 24 hours. The highest dilution which showed growth of the microorganism was considered as the Minimum Bactericidal Concentration (MBC). The purpose of this test was to determine the lowest concentration at which the ethyl acetate extract would kill $E$. coli and P. aeruginosa (Baris et al., 2006).

Isolation and purification of active compounds from the bioactive fractions

The most active crude extract (Ethyl acetate extract) was subjected to silica gel (70230 mesh) column chromatography. The column was first eluted with n-hexane as the mobile phase with the polarity increasing by $5 \%$ increments of ethyl acetate. After getting to $100 \%$ ethyl acetate, the polarity was further increased by $5 \%$ increments of methanol. The collected fractions were concentrated to dryness using a rotary evaporator at $40{ }^{0} \mathrm{C}$. The fractions were further fractionated using sephadex LH-20 by column chromatography with dichloromethane and methanol $(1: 1 ; \mathrm{v} / \mathrm{v})$ as the eluent system to obtain the pure compounds (Harvey, 2000).

\section{Structure determination of the bioactive compounds}

The structures of the bioactive compounds were determined using spectroscopic methods; Mass spectrometry (MS) and Nuclear magnetic resonance (NMR) spectroscopy. For MS, $0.5 \mathrm{mg}$ of each pure compound was put in a labeled sample vial and diluted with an appropriate solvent of HPLC grade up to a concentration of one micro molar $(1 \mu \mathrm{M})$. The solution in each case was filtered in order to remove any insoluble material which would otherwise block the sample introduction line. Two $\mathrm{ml}$ of each sample solution was introduced into the mass spectrometer for analysis. For NMR, both one dimensional (1D) and two dimensional (2D) proton $\left({ }^{1} \mathrm{H}\right)$ and carbon $\left({ }^{13} \mathrm{C}\right)$ NMR experiments such as COSY, NOESY, HMBC and HSQC were employed. The $1 \mathrm{D}$ and 2D spectra were recorded on Bruker AV-600 instruments (McMurry, 2000). All the spectra were analysed and the results compared with published information in literature in order to elucidate the structures of the isolated compounds.

(+)-catechin $(\mathbf{5})$

Dark brown powder, soluble in acetone: $\delta_{\mathrm{H}}{ }^{1} \mathrm{H}$ NMR $(600 \mathrm{MHz}, \mathrm{MeOH}): \delta_{\mathrm{C}}$ ${ }^{13} \mathrm{C}$ NMR (600 MHz, Acetone): $\delta_{\mathrm{H}}{ }^{1} \mathrm{H}$ NMR (600 MHz): $4.56(\mathrm{H}-2), 4.00(\mathrm{H}-3), 2.93(\mathrm{H}-$ 4a), 6.03 (d H-6), 5.88 (d, H-8), 6.9 (d, H-2'), $6.76\left(\mathrm{dd}, \mathrm{H}-6^{\prime}\right) ; \delta_{\mathrm{C}}{ }^{13} \mathrm{C} \mathrm{NMR}(600 \mathrm{MHz})$ : 82.7 (C-2), 68.3 (C-3), 28.8 (C-4A), 100.6 (C4a), 157.2 (C-5), 96.1 (C-6), 157.7 (C-7), 95.4 (C-8), 156.9 (C-8a), 132.2 (C-1'), 115.2 (C2'), 145.6 (C-3'), 145.7 (C-4'), 115.7 (C-5'), 120.1 (C-6').

Benzoyl alcohol (6)

Brown powder; $\delta_{\mathrm{H}}{ }^{1} \mathrm{H}$ NMR $(600 \mathrm{MHz}$, $\mathrm{MeOH}): 7.33$ (H-2), 7.33 (H-3), 7.33 (H-4), 7.33 (H-5), 7.33 (H-6), 4.58 (2H-7); $\delta_{\mathrm{C}}{ }^{13} \mathrm{C}$ NMR (600 MHz, Acetone): 142.7 (C-1), 128.0 (C-2), 129.4 (C-3), 128.3 (C-4), 129.4 (C-5), 128.0 (C-6), 65.3 (C-7). 


\section{RESULTS}

\section{In vitro activity of the crude extracts against selected bacteria}

The ethylacetate extract yielded $83.06 \mathrm{~g}$ of a brick red powder upon concentration. The methanol extract yielded $127 \mathrm{~g}$ of a dark coloured powder while the aqueous extract yielded $4.26 \mathrm{~g}$ of a brown powder. Three grams $(3 \mathrm{~g})$ of each extract was subjected to bioactivity tests. When the activity of the plant extracts were tested against two bacterial strains namely: Escherichia coli and Pseudomonas aeruginosa. The ethyl acetate extract's zone of inhibition diameter was 18 $\mathrm{mm}$ and $17 \mathrm{~mm}$ for Escherichia coli and Pseudomonas aeruginosa respectively (Table $1)$; while the methanol extract exhibited a zone of inhibition diameter of $8 \mathrm{~mm}$ against Pseudomonas aeruginosa and had no inhibition of growth on Escherichia coli. The aqueous extract had no inhibition of growth of any of the bacterial strains tested (Table 1).

Both bacterial strains $(P$. aeruginosa and $E$. coli) were found to be susceptible to the ethyl acetate extract as the zone of inhibition diameters $(17 \mathrm{~mm}$ and $18 \mathrm{~mm}$ for $P$. aeruginosa and E.coli respectively, were within the range for standard antibiotics such as ampicillin (inhibition diameter 16-22 mm), doxycycline (inhibition diameter 18-24 mm) and tetracycline (inhibition diameter 18-25 $\mathrm{mm}$ ), as reported by the CLSI (2007). The methanol extract showed no antibacterial activity towards $E$. coli while the zone of inhibition diameter of $8 \mathrm{~mm}$ (Table 1) indicated that $P$. aeruginosa was resistant to the extract. The aqueous extract did not show any antibacterial activity towards both strains. The bioactivity results were considered evidence of the presence of more compounds in the ethyl acetate extract compared to the methanol and aqueous extracts, the probable reason being that the compounds in $A$. coriaria stem bark were more soluble in ethyl acetate as compared to methanol and water.

Since the ethyl acetate extract showed the largest zone of inhibition, it was considered for further tests. Its Minimum
Inhibitory Concentration (MIC) against each of the bacterial strains was investigated as well as its Minimum Bactericidal Concentration (MBC).

The ethyl acetate extract showed a MIC of $125 \mathrm{mg} / \mathrm{ml}$ on $E$. coli and $250 \mathrm{mg} / \mathrm{ml}$ on $P$. aeruginosa. This showed that the ethyl acetate extract was more effective against $E$. coli as compared to $P$. aeruginosa. The Minimum Bactericidal Concentration (MBC) of 125 $\mathrm{mg} / \mathrm{ml}$ on $E$. coli and none on $P$. aeruginosa also showed that the extract has a stronger activity towards $E$. coli than $P$. aeruginosa (Table 2). However, the high MIC values calls for a higher dose for effective treatment. This result supports the high dosage (3-4 cupfuls per day) used by the traditional healers for an adult (Namukobe et al., 2011).

\section{Characterization of the compounds in the most active (ethyl acetate) extract}

Six compounds were isolated from the ethyl acetate extract of the stem bark of $A$. coriaria by a combination of chromatographic techniques. The structures of these isolated compounds were identified by NMR spectroscopy and Mass spectrometry as Lupeol (1), Lupenone (2), Betulinic acid (3), Acacic acid lactone (4), (+) - Catechin (5) and Benzyl alcohol (6). This is the first time these compounds are being reported in this plant species.

Compound $\mathbf{1}$ was obtained as a white powder, soluble in methylene chloride, having been eluted with methylene chloride: methanol $(1: 1 ; \mathrm{v} / \mathrm{v})$ from the sephadex column. The mass spectrum of compound $\mathbf{1}$ exhibited a molecular ion $[\mathrm{M}]^{+}$peak at $\mathrm{m} / \mathrm{z}$ 426 observed from EI-MS. Fragments at $\mathrm{m} / \mathrm{z}$ 189 and 218, characteristic of pentacyclic triterpenes (Pereira et al., 1996) were also present. The other prominent fragment ion peak was at $\mathrm{m} / \mathrm{z} 411\left[\mathrm{M}-\mathrm{CH}_{3}\right]^{+}$, which is characteristic of a pentacyclic triterpene with an isopropenyl group (Pereira et al., 1996). Its molecular formula was assigned to be $\mathrm{C}_{30} \mathrm{H}_{50} \mathrm{O}$. 
The ${ }^{1} \mathrm{H}$ NMR spectrum of $\mathbf{1}$ showed resonances assignable to olefinic methylene protons at $4.68 \mathrm{ppm}$ and $4.55 \mathrm{ppm}$, a carbinyl proton at $3.15 \mathrm{ppm}$, a vinyl methyl singlet at $1.68 \mathrm{ppm}$, and six methyl singlets at 0.94 ppm, 0.74 ppm, 0.83 ppm, 1.03 ppm, 0.95 ppm and 0.79 ppm. The vinyl methyl at 1.68 ppm was found to be coupled to one of the two methylene protons ( $\mathrm{H}-29 \mathrm{~b}, 4.55 \mathrm{ppm})$ in the COSY experiment, thus indicating the presence of an isopropenyl group as well as a lupane skeleton (Shai et al., 2008). A methine signal at $2.40 \mathrm{ppm}(\mathrm{ddd}, J=11.1,11.1,5.8 \mathrm{~Hz})$ was attributed to the proton at $\mathrm{C}-19$ position (Tables 3 and 4 ). The ${ }^{13} \mathrm{C}$ NMR data of compound 1 were in agreement with the MS data, as it revealed 30 carbon signals, which were shown by the HSQC experiment to be seven methyls, ten methylene, six methine carbons, five quaternary carbons and two olefinic carbons. The ${ }^{13} \mathrm{C}$ NMR data was also in complete agreement with the existence of an isopropenyl group, in particular, the characteristic vinylic carbon atom resonances at $151.2 \mathrm{ppm}$ and $109.3 \mathrm{ppm}$, corresponding to carbon atoms 20 and 29 respectively. This supported the olefinic methylene protons seen as singlets at $4.68 \mathrm{ppm}$ and $4.55 \mathrm{ppm}$ in the ${ }^{1} \mathrm{H}$ NMR spectrum of compound $\mathbf{1}$. The signal at $78.7 \mathrm{ppm}$ was characteristic for the oxymethine carbon at position 3 . With the help of the HSQC experiment, a correlation was observed between the olefinic methylene protons: H-29a (4.68 ppm), H-29b (4.55 ppm) and C-29 (109.3 ppm) (Table 3). From the same spectrum, all the ${ }^{1} \mathrm{H}$ resonances were assigned to their corresponding ${ }^{13} \mathrm{C}$ resonances (Table 4). The HMBC spectrum of compound 1 showed correlations between the carbinyl proton, H-3 (3.15 ppm) and the carbon atoms C-24 (15.4 ppm) and C-23 (28.0 ppm) as well as between the olefinic methylene protons: H-29a (4.68 ppm), H-29b (4.55 ppm) and the carbon atoms C-30 (19.2 ppm) and C-19 (48.3 ppm) (Table 3). Several other correlations were observed from the HMBC spectrum of compound $\mathbf{1}$ that was helpful in the assignment of quaternary carbon atoms (Table 4). Several cross peaks were observed from the COSY spectrum of compound 1 (Figure 1) including those between H-29a (4.68 ppm) and H-30 (1.68 ppm), H-3 (3.15 ppm) and H-2 (1.55 ppm), H19 (2.40 ppm) and H-18 (1.37 ppm) as well as that between $\mathrm{H}-21 \mathrm{a}(1.92 \mathrm{ppm})$ and $\mathrm{H}-22 \mathrm{a}$ (1.37 ppm). The spatial arrangement of the olefinic methylene protons (H-29a and $\mathrm{H}-29 \mathrm{~b}$ ) was assigned basing on their coupling constants. H-29a (4.68 ppm) was observed as a doublet $(J=2.5 \mathrm{~Hz})$ in the ${ }^{1} \mathrm{H}$ spectrum of compound $\mathbf{1}$, hence suggesting its coupling with H-30. This supports its position that is trans to C-30 (Figure 1). H-29b (4.55 ppm) was observed as a triple doublet $(J=2.7 \mathrm{~Hz}$, $2.6 \mathrm{~Hz}, 1.3 \mathrm{~Hz})$. This suggested its coupling with H-19 $(J=2.7 \mathrm{~Hz}), \mathrm{H}-30(J=2.6 \mathrm{~Hz})$ and $\mathrm{H}-18(J=1.3 \mathrm{~Hz})$. H-29b was therefore assigned the position that is cis to $\mathrm{C}-30$. The spectral evidence given above, as well as the ${ }^{1} \mathrm{H}$ and ${ }^{13} \mathrm{C}$ NMR chemical shifts (Table 4 ) of compound 1 were found to be in close agreement with the ${ }^{1} \mathrm{H}$ and ${ }^{13} \mathrm{C}$ NMR chemical shifts reported for Lupeol isolated from Holarrhena floribunda (Fotie et al., 2006). Hence compound $\mathbf{1}$ was assigned as Lupeol (Figure 1).

Compound 2 was obtained as brown oil, soluble in methylene chloride, having been eluted with methylene chloride: hexane $(1: 1 ; \mathrm{v} / \mathrm{v})$ from the silica column. The mass spectrum of compound $\mathbf{2}$ exhibited a molecular ion peak $[\mathrm{M}]^{+}$at $m / z \quad 424$, corresponding to a molecular formula $\mathrm{C}_{30} \mathrm{H}_{48} \mathrm{O}$. Fragments at $\mathrm{m} / \mathrm{z} 203$ and 218, characteristic of pentacyclic triterpenes (Pereira et al., 1996) were also present in the mass spectrum of compound 2. The mass spectrometry data also suggested the presence of a carbonyl group (fragment at $\mathrm{m} / \mathrm{z} 205$ ) and the accurate mass of this fragment indicated that it was attached to rings $\mathrm{A}$ or $\mathrm{B}$ of the pentacyclic ring (Pereira et al., 1996). The fragment at 409 corresponding to $\left[\mathrm{M}-\mathrm{CH}_{3}\right]^{+}$ was also observed.

The ${ }^{1} \mathrm{H}$ and ${ }^{13} \mathrm{C}$ NMR data of compound $\mathbf{2}$ were similar to those of 
compound 1 suggesting structural similarity of the two compounds (Tables 3 and 4). However, the ${ }^{1} \mathrm{H}$ NMR spectrum of compound 2 did not show the carbinyl proton signal at $3.15 \mathrm{ppm}$ as was the case for compound 1. In addition, the ${ }^{13} \mathrm{C}$ NMR of spectrum of 2 showed a resonance at $218.0 \mathrm{ppm}$, assigned to a carbonyl carbon (Table 4). The existence of the carbonyl group was further supported by the fragment observed at $\mathrm{m} / \mathrm{z} 205$ in the mass spectrum of compound 2 . The assignment of this carbonyl group to position 3 in ring A was possible from the results of a COSY experiment clearly showing the coupling between the two hydrogen atoms at position 2 and those at position 1 . The ${ }^{1} \mathrm{H}$ and ${ }^{13} \mathrm{C}$ NMR chemical shifts (Tables 3 and 4) of compound 2 were found to be in close agreement with the ${ }^{1} \mathrm{H}$ and ${ }^{13} \mathrm{C}$ NMR chemical shifts and structure reported for Lupenone isolated from Glochidion sphaerogynum (Puapairoj et al., 2005). Hence compound 2 was assigned as Lupenone (Figure 1).

Compound 3 was obtained as a white amorphous powder, soluble in methanol, having been eluted with methylene chloride: methanol $(9: 1 ; \mathrm{v} / \mathrm{v})$ from the silica gel column. The NMR spectral data of compound $\mathbf{3}$ were very similar to those of compound $\mathbf{1}$ and 2. The ${ }^{1} \mathrm{H}$ and ${ }^{13} \mathrm{C}$ NMR chemical shifts (Tables 3 and 4) of compound $\mathbf{3}$ were found to be in close agreement with the ${ }^{1} \mathrm{H}$ and ${ }^{13} \mathrm{C}$ NMR chemical shifts and structure reported for Betulinic acid (Sholichin et al., 1980). Compound $\mathbf{3}$ was therefore assigned as Betulinic acid (Figure 1).

Compound 4 was obtained as a white amorphous powder, soluble in methanol. It was eluted with methylene chloride: methanol (98:2; v/v) from the silica column. The ${ }^{1} \mathrm{H}$ and ${ }^{13} \mathrm{C}$ NMR chemical shifts (Tables 3 and 4 ) of compound 4 were found to be consistent with the ${ }^{1} \mathrm{H}$ and ${ }^{13} \mathrm{C}$ NMR chemical shifts and structure reported for Acacic acid lactone

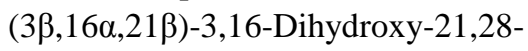

epoxyolean-12-en-28-one) isolated from Albizia versicolor (Rukunga and Waterman, 2001). Hence compound 4 was identified as Acacic acid lactone (Figure 1). In a similar manner as in the above compounds (1-4), ${ }^{1} \mathrm{H}$ and ${ }^{13} \mathrm{C}$ NMR data of compounds 5 and 6 were identified as $(+)$ - catechin (Davis et al., 1996) and benzyl alcohol (Figure 2) respectively $\left({ }^{1} \mathrm{H}\right.$ and ${ }^{13} \mathrm{C}$ NMR data under materials and methods section).

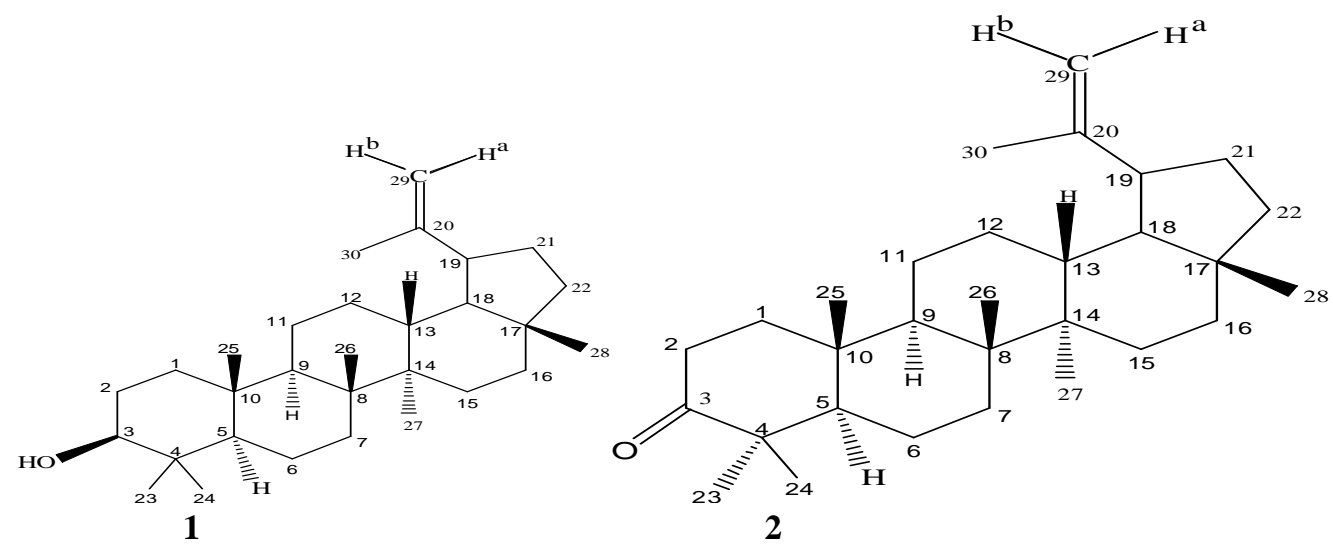



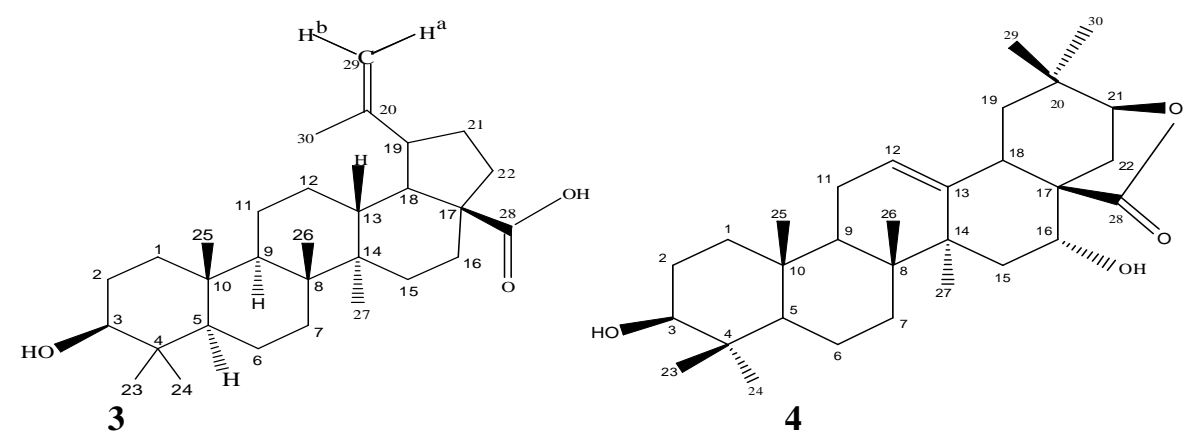

Figure 1: The structure of compounds. 1 (Lupeol), 2 (Lupenone), 3 (Betulinic acid) and $\mathbf{4}$ (Acacic acid lactone) isolated from ethylacetate of A. coriaria.<smiles>Oc1cc(O)c2c(c1)O[C@H](c1ccc(O)c(O)c1)C(O)C2</smiles><smiles>OCc1ccccc1</smiles>

Figure 2: The structure of compound 5; (+) - catechin and 6; benzyl alcohol.

Table 1: Antibacterial activity of plant extracts against Pseudomonas aeruginosa and Escherichia coli.

\begin{tabular}{|c|c|c|c|c|c|c|}
\hline \multirow{3}{*}{$\begin{array}{l}\text { Micro- } \\
\text { organisms }\end{array}$} & \multicolumn{6}{|c|}{ Diameter of inhibition zone (mm) } \\
\hline & \multicolumn{3}{|c|}{ Extract } & \multicolumn{3}{|c|}{ Controls } \\
\hline & $\begin{array}{l}\text { Ethylacetate } \\
(1000 \mathrm{mg} / \mathrm{ml})\end{array}$ & $\begin{array}{c}\text { Methanol } \\
(1000 \mathrm{mg} / \mathrm{ml})\end{array}$ & $\begin{array}{c}\text { Aqueous } \\
(1000 \mathrm{mg} / \mathrm{ml})\end{array}$ & $\begin{array}{c}\text { Positive } \\
\text { (Cipro, } \\
0.5 \mathrm{mg} / \mathrm{ml} \text { ) }\end{array}$ & $\begin{array}{l}\text { Negative } \\
\text { (DMSO) }\end{array}$ & Blank \\
\hline E. coli & $18^{\mathrm{a}}$ & $0^{\mathrm{c}}$ & $0^{\mathrm{e}}$ & 48 & 0 & 0 \\
\hline P. aeruginosa & $17^{\mathrm{b}}$ & $8^{\mathrm{d}}$ & $0^{\mathrm{f}}$ & 49 & 0 & 0 \\
\hline
\end{tabular}

Table 2: Minimum Inhibitory Concentration (MIC) and Minimum Bactericidal Concentration (MBC) of the ethyl acetate extract.

\begin{tabular}{lcc}
\hline Microorganism & MIC in $\mathbf{~ m g / m l}$ & MBC in $\mathbf{~ m g} / \mathbf{m l}$ \\
\hline E. coli $($ ATCC25922) & 125 & 125 \\
$P$. aeruginosa & 250 & Not detected \\
\hline
\end{tabular}


Table 3: ${ }^{1} \mathrm{H}(600 \mathrm{MHz})$ NMR spectral data for compound 1-4 in isolated from the stem bark of Albizia coriaria recorded in $\mathrm{CD}_{2} \mathrm{Cl}_{2}(\delta$ in parts per million, $\mathrm{J}$ in Hertz) $)^{\mathrm{a}}$.

\begin{tabular}{|c|c|c|c|c|}
\hline$\#$ & 1(ppm, Hz) & 2 (ppm, Hz) & 3 (ppm, Hz) & $4(\mathrm{ppm}, \mathrm{Hz})$ \\
\hline $1 \mathrm{a}$ & $1.65(\mathrm{~m})$ & $1.6(\mathrm{~m})$ & $1.67(\mathrm{~m})$ & $1.63(\mathrm{~m})$ \\
\hline $1 \mathrm{~b}$ & $0.91(\mathrm{~m})$ & $0.92(\mathrm{~m})$ & $0.92(\mathrm{~m})$ & $1.00(\mathrm{~m})$ \\
\hline \multirow[t]{2}{*}{2} & $1.55(\mathrm{~m})$ & $1.55(\mathrm{~m})$ & $1.60(\mathrm{~m})$ & $1.63(\mathrm{~m})$ \\
\hline & & & $1.56(\mathrm{~m})$ & $1.57(\mathrm{~m})$ \\
\hline 3 & $3.15(\mathrm{dd}, 10.6,5.91)$ & & $3.13(\mathrm{dd}, 11.4,4.7)$ & $3.15(\mathrm{dd}, 11.4,4.7)$ \\
\hline 5 & $0.70(\mathrm{~m})$ & $0.60(\mathrm{~m})$ & $0.70(\mathrm{~m})$ & $0.78(\mathrm{~m})$ \\
\hline $6 a$ & $1.51(\mathrm{~m})$ & $1.51(\mathrm{~m})$ & $1.53(\mathrm{~m})$ & $1.63(\mathrm{~m})$ \\
\hline $6 b$ & $1.40(\mathrm{~m})$ & $1.40(\mathrm{~m})$ & $1.41(\mathrm{~m})$ & $1.51(\mathrm{~m})$ \\
\hline 7 & $1.34(\mathrm{~m})$ & $1.34(\mathrm{~m})$ & $1.42(\mathrm{~m})$ & $1.55(\mathrm{~m})$ \\
\hline 9 & $1.26(\mathrm{dd}, 12.9,2.7)$ & $1.22(\mathrm{dd}, 12.9,2.7)$ & $1.62(\mathrm{~m})$ & $1.52(\mathrm{~m})$ \\
\hline $11 \mathrm{a}$ & $1.40(\mathrm{~m})$ & $1.40(\mathrm{~m})$ & $1.44(\mathrm{dd}, 8.9,2.8)$ & $1.96(\mathrm{dd}, 8.9,2.8)$ \\
\hline $11 b$ & $1.20(\mathrm{~m})$ & $1.12(\mathrm{~m})$ & & \\
\hline $12 \mathrm{a}$ & $1.67(\mathrm{~m})$ & $1.64(\mathrm{~m})$ & $1.67(\mathrm{~m})$ & $5.42(\mathrm{~d}, 3.2)$ \\
\hline $12 b$ & $1.09(\mathrm{dd}, 13.3,4.8)$ & $1.08(\mathrm{dd}, 13.3,4.8)$ & $1.09(\mathrm{dd}, 13.3,4.8)$ & \\
\hline 13 & $1.67(\mathrm{~m})$ & $1.64(\mathrm{~m})$ & $1.67(\mathrm{~m})$ & \\
\hline $15 \mathrm{a}$ & $1.69(\mathrm{~m})$ & $1.71(\mathrm{~m})$ & $1.97(\mathrm{dd}, 14.1,5.0)$ & $2.04(\mathrm{dd}, 14.1,5.0)$ \\
\hline $15 b$ & $1.01(\mathrm{ddd}, 13.8,4.2,2.5)$ & $1.01(\mathrm{ddd}, 13.8,4.2,2.5)$ & $1.90(\mathrm{dd}, 14.0,12.2)$ & $1.12(\mathrm{dd}, 14.0,12.2)$ \\
\hline 16 & $1.47(\mathrm{ddd}, 12.9,4.5,2.7)$ & $1.47(\mathrm{ddd}, 12.9,4.5,2.7)$ & $2.27(\mathrm{ddd}, 12.9,4.5,2.7)$ & $3.90(\mathrm{dd}, 11.8,4.7)$ \\
\hline 18 & $1.37(\mathrm{~m})$ & $1.35(\mathrm{~m})$ & $1.34(\mathrm{dd}, 11.9,6.4)$ & $2.51(\mathrm{dd}, 11.9,6.4)$ \\
\hline 19 & $2.40(\mathrm{ddd}, 11.1,11.1,5.8)$ & $2.40(\mathrm{ddd}, 11.1,11.1,5.8)$ & $2.40(\mathrm{ddd}, 11.1,11.1,5.8)$ & $\begin{array}{c}1.82(\mathrm{t}, 13.4) \\
1.39(\mathrm{dd}, 14.3,6.6)\end{array}$ \\
\hline $21 \mathrm{a}$ & $1.92(\mathrm{dddd}, 13.5,10.5,10.5,8.6)$ & 2.03 (dddd, $13.5,10.5,10.5,8.6)$ & 2.03 (dddd, $13.5,10.5,10.5,8.6)$ & $4.26(\mathrm{~d}, 5.5)$ \\
\hline $21 b$ & $1.31(\mathrm{~m})$ & $1.31(\mathrm{~m})$ & $1.31(\mathrm{~m})$ & \\
\hline
\end{tabular}


R. BYAMUKAMA et al. / Int. J. Biol. Chem. Sci. 9(2): 1013-1024, 2015

\begin{tabular}{lcccc}
\hline $22 \mathrm{a}$ & $1.37(\mathrm{~m})$ & $1.37(\mathrm{~m})$ & $1.70(\mathrm{~m})$ & $2.33(\mathrm{~m})$ \\
$22 \mathrm{~b}$ & $1.20(\mathrm{~m})$ & $1.20(\mathrm{~m})$ & 0.94 & 0.89 \\
23 & 0.94 & 0.92 & 0.98 & 0.75 \\
24 & 0.74 & 0.74 & 0.96 & 0.95 \\
25 & 0.83 & 0.84 & 0.97 & 0.93 \\
26 & 1.03 & 1.04 & 4.25 \\
27 & 0.95 & 0.97 & $4.70(\mathrm{~d}, 2.5)$ \\
28 & 0.79 & 0.79 & $4.59(\mathrm{ddd}, 2.7,2.6,1.3)$ \\
$29 \mathrm{a}$ & $4.68(\mathrm{~d}, 2.5)$ & $4.74(\mathrm{~d}, 2.5)$ & 1.69 \\
$29 \mathrm{~b}$ & $4.55(\mathrm{ddd}, 2.7,2.6,1.3)$ & $4.60(\mathrm{ddd}, 2.7,2.6,1.3)$ & 0.99 \\
30 & $1.68(\mathrm{~m})$ & $1.68(\mathrm{~m})$ &
\end{tabular}

ad, doublet; $m$, multiplet 
Table 4: ${ }^{13} \mathrm{C}(600 \mathrm{MHz})$ NMR spectral data for compound 1-4 in isolated from the stem bark of Albizia coriaria recorded in $\mathrm{CD}_{2} \mathrm{Cl}_{2}$ ( $\delta$ in parts per million).

\begin{tabular}{|c|c|c|c|c|}
\hline & 1 & 2 & 3 & 4 \\
\hline $\begin{array}{l}1 \mathrm{a} \\
1 \mathrm{~b}\end{array}$ & $38.7 \mathrm{CH}_{2}$ & $38.7 \mathrm{CH}_{2}$ & $38.5 \mathrm{CH}_{2}$ & $40.0 \mathrm{CH}_{2}$ \\
\hline 2 & $27.7 \mathrm{CH}_{2}$ & $27.9 \mathrm{CH}_{2}$ & $27.2 \mathrm{CH}_{2}$ & $28.0 \mathrm{CH}_{2}$ \\
\hline 3 & $78.7 \mathrm{CH}$ & $218.0 \mathrm{C}$ & $78.2 \mathrm{CH}$ & $79.7 \mathrm{CH}$ \\
\hline 4 & $38.8 \mathrm{C}$ & $40.0 \mathrm{C}$ & $40.5 \mathrm{C}$ & $39.9 \mathrm{C}$ \\
\hline 5 & $55.2 \mathrm{CH}$ & $55.4 \mathrm{CH}$ & $55.5 \mathrm{CH}$ & $57.0 \mathrm{CH}$ \\
\hline $\begin{array}{l}6 \mathrm{a} \\
6 \mathrm{~b}\end{array}$ & $18.3 \mathrm{CH}_{2}$ & $20.18 \mathrm{CH}_{2}$ & $18.0 \mathrm{CH}_{2}$ & $19.5 \mathrm{CH}_{2}$ \\
\hline 7 & $34.2 \mathrm{CH}_{2}$ & $34.9 \mathrm{CH}_{2}$ & $34.2 \mathrm{CH}_{2}$ & $33.5 \mathrm{CH}_{2}$ \\
\hline 8 & $40.8 \mathrm{C}$ & $41.3 \mathrm{C}$ & $42.2 \mathrm{C}$ & $41.5 \mathrm{C}$ \\
\hline 9 & $50.4 \mathrm{CH}$ & $50.2 \mathrm{CH}$ & $50.6 \mathrm{CH}$ & $48.5 \mathrm{CH}$ \\
\hline 10 & $37.1 \mathrm{C}$ & $37.4 \mathrm{C}$ & $36.9 \mathrm{C}$ & $38.3 \mathrm{C}$ \\
\hline $\begin{array}{l}11 \mathrm{a} \\
11 \mathrm{~b}\end{array}$ & $20.9 \mathrm{CH}_{2}$ & $21.4 \mathrm{CH}_{2}$ & $20.7 \mathrm{CH}_{2}$ & $24.7 \mathrm{CH}_{2}$ \\
\hline $\begin{array}{l}12 \mathrm{a} \\
12 \mathrm{~b}\end{array}$ & $25.2 \mathrm{CH}_{2}$ & $26.9 \mathrm{CH}_{2}$ & $25.5 \mathrm{CH}_{2}$ & $126.1 \mathrm{CH}$ \\
\hline 13 & $38.7 \mathrm{CH}$ & $37.4 \mathrm{CH}$ & $38.5 \mathrm{CH}$ & $140.8 \mathrm{C}$ \\
\hline 14 & $43.0 \mathrm{C}$ & $43.4 \mathrm{C}$ & $42.1 \mathrm{C}$ & $44.4 \mathrm{C}$ \\
\hline $\begin{array}{l}15 \mathrm{a} \\
15 \mathrm{~b}\end{array}$ & $27.7 \mathrm{CH}_{2}$ & $29.9 \mathrm{CH}_{2}$ & $31.7 \mathrm{CH}_{2}$ & $38.3 \mathrm{CH}_{2}$ \\
\hline 16 & $35.5 \mathrm{CH}_{2}$ & $36.0 \mathrm{CH}_{2}$ & $34.2 \mathrm{CH}_{2}$ & $68.0 \mathrm{CH}$ \\
\hline 17 & $43.2 \mathrm{C}$ & $43.5 \mathrm{C}$ & $50.6 \mathrm{C}$ & $50.8 \mathrm{C}$ \\
\hline 18 & $48.4 \mathrm{CH}$ & $48.7 \mathrm{CH}$ & $47.8 \mathrm{CH}$ & $42.8 \mathrm{CH}$ \\
\hline 19 & $48.3 \mathrm{CH}$ & $48.5 \mathrm{CH}$ & $49.0 \mathrm{CH}$ & $44.4 \mathrm{CH}_{2}$ \\
\hline 20 & $151.2 \mathrm{C}$ & $151.6 \mathrm{C}$ & $150.5 \mathrm{C}$ & $35.0 \mathrm{C}$ \\
\hline $\begin{array}{l}21 \mathrm{a} \\
21 \mathrm{~b}\end{array}$ & $29.8 \mathrm{CH}_{2}$ & $32.5 \mathrm{CH}_{2}$ & $29.4 \mathrm{CH}_{2}$ & $85.3 \mathrm{CH}$ \\
\hline $\begin{array}{l}22 \mathrm{a} \\
22 \mathrm{~b}\end{array}$ & $40.2 \mathrm{CH}_{2}$ & $40.4 \mathrm{CH}_{2}$ & $36.7 \mathrm{CH}_{2}$ & $27.5 \mathrm{CH}_{2}$ \\
\hline 23 & $28.0 \mathrm{CH}_{3}$ & $23.2 \mathrm{CH}_{3}$ & $28.2 \mathrm{CH}_{3}$ & $28.8 \mathrm{CH}_{3}$ \\
\hline 24 & $15.4 \mathrm{CH}_{3}$ & $20.1 \mathrm{CH}_{3}$ & $15.4 \mathrm{CH}_{3}$ & $16.4 \mathrm{CH}_{3}$ \\
\hline 25 & $16.1 \mathrm{CH}_{3}$ & $14.4 \mathrm{CH}_{3}$ & $16.1 \mathrm{CH}_{3}$ & $16.2 \mathrm{CH}_{3}$ \\
\hline 26 & $16.0 \mathrm{CH}_{3}$ & $16.1 \mathrm{CH}_{3}$ & $16.7 \mathrm{CH}_{3}$ & $16.8 \mathrm{CH}_{3}$ \\
\hline 27 & $14.5 \mathrm{CH}_{3}$ & $14.8 \mathrm{CH}_{3}$ & $14.8 \mathrm{CH}_{3}$ & $29.3 \mathrm{CH}_{3}$ \\
\hline 28 & $18.0 \mathrm{CH}_{3}$ & $18.0 \mathrm{CH}_{3}$ & $176.3 \mathrm{C}$ & $183.2 \mathrm{C}$ \\
\hline $\begin{array}{l}29 a \\
29 b\end{array}$ & $109.3 \mathrm{CH}_{2}$ & $109.6 \mathrm{CH}_{2}$ & $108.8 \mathrm{CH}_{2}$ & $29.1 \mathrm{CH}_{3}$ \\
\hline 30 & $19.2 \mathrm{CH}_{3}$ & $21.9 \mathrm{CH}_{3}$ & $19.5 \mathrm{CH}_{3}$ & $24.2 \mathrm{CH}_{3}$ \\
\hline
\end{tabular}

\section{DISCUSSION}

Several authors have reported a wide spectrum of pharmacological activities of lupeol against various disease conditions such as inflammation, arthritis, diabetes, cardiovascular ailments, renal disorder, hepatic toxicity, microbial infections, cancer and inhibition of the growth of a variety of pathogenic fungal species (Fotie et al., 2006; Siddique and Saleem, 2011). Lupenone is reported to have antimicrobial potential as it exhibited antifungal activity against C.albicans, Trichophyton mentagrophytes and Aspergillus niger (Po-wei et al., 2012). It 
is also reported to have exhibited low antibacterial activity against staphylococcus aureus, E.coli, P.aeruginosa and partial inhibition of bacillus subtilis (Po-wei et al., 2012). Betulinic acid is reported to have antiviral, antiplasmodial, antibacterial (against E.coli and staphylococcus aureus), anthelmintic as well as antidepressant effects (Carmona et al., 2010; Hess et al., 1995; Machado et al., 2013; Shai et al., 2008). (+) Catechin is reported to exhibit physiological effects, including antibacterial, antifungal, antiviral, antioxidative and antitumor activities (Tamura and Ochiai, 2012). All these reported pharmacological effects supports the use A. coriaria in traditional medicine against several disease conditions such as diarrhoea, skin infections, candida albicans and respiratory diseases.

\section{Conclusion}

In this study, six compounds have been isolated and characterized from the stem bark of Albizia coriaria as: Lupeol (1), Lupenone (2), Betulinic acid (3), Acacic acid lactone (4), $(+)$ - Catechin (5) and Benzyl alcohol (6). This therefore is the first time these compounds are reported in this plant. The compounds that have been characterized in this study exhibited a wide range of bioactivity on bacterial growth as reported in the previous studies. This, coupled with the findings from the bioassay studies on the crude extract, justify the use of Albizia coriaria in traditional medicine. Furthermore, standardization of herbal formulations from Albizia coriaria bark can be possible by using the characterized compounds as markers in the improved traditional medicine.

\section{ACKNOWLEDGEMENTS}

The authors are grateful to Prof. Erich Kleinpeter for invitation and host of G. Barbara at the Institut für Chemie, Universität, Potsdam University, Germany for NMR analysis of the samples and DAAD for financial support.

\section{REFERENCES}

Abdel-Kader M, Hoch J, Berger JM, Evans R, Miller JS, Wisse JH, Mamber SW, Dalton JM, Kingston DGI. 2001. Two bioactive saponins from Albizia subdimidiata from the Suriname rainforest. J. Nat. Products, 64: 536-539.

Baris O, Gulluce M, Sahin F, Ozer H, Kilic H, Ozkan H, Sokmen M, Ozbek T. 2006. Biological activities of the essential oil and methanol extract of Achillea Biebersteinii Afan. (Asteraceae). Turk. J. Biol., 30: 6573.

Carmona DB, Erosa FE, Sosa KG, Pinell GR, Yapu DG, Bacab MJ, Turba AG, Rodr'iguez LM. 2010. Antiprotozoal activity of Betulinic acid derivatives. Phytomed., 17: 379-382.

Carpani G, Orsini F, Sisti M, Verotta L. 1989. Saponins from Albizia anthelmintica. Phytochem., 28: 863-866.

CLSI (Clinical and Laboratory Standards Institute). 2007. Performance standards for antimicrobial susceptibility testing, Seventeenth Informational Supplement, 27(1).

Davis AL, Cai Y, Davies AP, Lewis JR. 1996. ${ }^{1} \mathrm{H}$ and ${ }^{13} \mathrm{C}$ Assignments of some Green Tea Polyphenols. Magn. Res. Chem., 34: 887-890.

Fotie J, Bohle DS, Leimanis ML, Georges E, Rukunga G, Nkengfack AE. 2006. Lupeol Long-Chain Fatty Acid Esters with Antimalarial Activity from Holarrhena floribunda. J. Nat. Prod., 69: 63-69.

Harvey D. 2000. Modern Analytical Chemistry ( $1^{\text {st }}$ edn). McGraw-Hill: UK; 547-589.

Hess SC, Brum RL, Honda NK, Cruz AB, Moretto E, Cruz RB, Messana I, Ferrari F, Filho VC, Yunes RA. 1995. Antibacterial activity and phytochemical analysis of Vochysia divergens. J. Ethnopharma, 47: 97-100.

Kigondu EVM, Rukunga GM, Keriko JM, Tonui WK, Gathirwa JW, Kirira PG, Irungu B, Ingonga JM, Ndiege IO. 2009. Anti-parasitic activity and cytotoxicity of 
selected medicinal plants from Kenya. $J$. Ethnopharma, 123: 504-509.

Krief S, Thoison O, Sevenet T, Wrangham RW, Lavaud C. 2005. Triterpenoid saponins anthranilates from Albizia grandibracteata leaves ingested by primates in Uganda. J. Nat. Prod., 68: 897-903.

Machado DG, Cunha MP, Neis VB, Balen GO, Colla A, Bettio LEB, Oliveira A, Pazini FL, Dalmarco JB, Simionatto EL, Pizzolatti MG, Rodrigues AS. 2013. Antidepressant-like effects of fractions, essential oil, carnosol and betulinic acid isolated from Rosmarinus officinalis. Food Chem., 136: 999-1005.

McMurry J. 2000. Organic Chemistry $\left(5^{\text {th }}\right.$ edn). Cornell University. Brooks/Cole; 441-449.

Namukobe J, Kasenene JM, Kiremire BT, Byamukama R, Mugisha MK, Krief S, Dumontet V, Kabasa JD. 2011. Traditional plants used for medicinal purposes by local communities around the Northern sector of Kibale National Park, Uganda. J. Ethnopharma, 136: 236-245.

Orsini F, Pelizzoni F, Verotta L. 1991. Saponins from Albizia lucida. Phytochemistry, 30: 4111-4115.

Pal BC, Achari B, Yoshikawa K, Arihara S. 1995. Saponins from Albizia lebbeck. J. Phytochem., 38: 1287-1291.

Pereira FBM, Domingues FMJ, Silva AMS. 1996. Triterpenes from Acacia dealbata. Nat. Prod. Lett., 8: 97-103.

Po-wei T, Kathlia DA, Chang SC, Consolacion RY. 2012. Chemical constituents of Broussonetia luzonicus. Pharmacognosy J., 4: 31-56.

Puapairoj P, Naengchomnong W, Kijjoa A, Pinto MM, Pedro M, Nascimento MS,
Silva AMS, Herz W. 2005. Cytotoxic activity of Lupane-type triterpenes from Glochidion sphaerogynum and Glochidion eriocarpum two of which induce apoptosis. Planta, 71: 208-213.

Rukunga GM, Waterman PG. 2001. Triterpenes of Albizia Versicolor and Albizia schimperana stem barks. Fitoterapia, 72: 188-190.

Shai LJ, McGaw LJ, Aderogba MA, Mdee LK, Eloff JN. 2008. Four pentacyclic triterpenoids with antifungal and antibacterial activity from Curtisia dentata leaves. J. Ethnopharma, 119: 238-244.

Sholichin M, Yamasaki K, Kasai R, Tanaka O. $1980 .{ }^{13} \mathrm{C}$ Nuclear magnetic resonance of lupane-type triterpenes, lupeol, betulin and betulinic acid. Chem. Pharm. Bull., 28: 1006-1008.

Siddique HR, Saleem H. 2011. Beneficial health effects of lupeol triterpene: A review of preclinical studies. Life Sciences, 88: 285-293.

Tabuti JRS, Mugula BB. 2007. The ethnobotany and ecological status of Albizia coriaria in Budondo Sub-county, eastern Uganda. Afri. J. Ecol., 45(3): 126129.

Tamura M, Ochiai K. 2012. Exploring the possible applications of catechin (gel) for oral care of the elderly and disabled individuals. Japanese Dental Sci. Rev., 48: 126-134.

Yoshikawa K, Satou Y, Tokunaga Y, Tanaka M, Arihara S, Nigam SK. 1998. Four acylated triterpenoid saponins from Albizia procera. J. Nat. Prod., 61: 440-445.

Zheng L, Zheng J, Zhao Y, Wang B, Wu L, Liang H. 2006. Three anti-tumor saponins from Albizia julibrissin. Bioorg. Medicinal Chem. Lett., 16: 2765-2768. 